\title{
Patients Access to Medicines - A Critical Review of the Healthcare System in Kenya
}

\author{
Anthony Martin Toroitich $\mathbb{D}^{1,2}$, Louise Dunford ${ }^{3}$, Rachel Armitage $\mathbb{D}^{4}$, Sangeeta Tanna $\mathbb{D}^{2}$ \\ 'Trade Affairs Department, Pharmacy and Poisons Board, Nairobi, Kenya; ${ }^{2}$ Leicester School of Pharmacy, De Montfort University, Leicester, UK; \\ ${ }^{3}$ Leicester School of Allied Health Sciences, De Montfort University, Leicester, UK; ${ }^{4}$ Faculty of Health and Life Sciences, De Montfort University, \\ Leicester, UK
}

Correspondence: Anthony Martin Toroitich, Leicester School of Pharmacy, De Montfort University, The Gateway, Leicester, LEI 9BH, UK, Tel +254724065344, Email P2539250@my365.dmu.ac.uk

\begin{abstract}
Access to affordable, safe, effective, and quality-assured medicines by a patient is important for good health outcomes. Unfortunately, there is sparse literature published on the pharmaceutical enablers that may increase the sale of a substandard and falsified (SF) medicine to a patient in Kenya. The review highlights some of the factors that may facilitate the entry of SF medicines into the legitimate pharmaceutical supply chain and discusses their impact on patient access to medicines. Lack of essential medicines in public health facilities is an important factor that may contribute to increased demand for medicine-related out-of-pocket expenses from private health facilities, thus a likelihood for a patient purchasing SF medicine from unlicensed and illegal medicine outlets or unregulated websites. The need to increase medicine availability in the public sector by the Ministry of Health (MOH) is emphasized in addition to the strengthening of public procurement to cushion it from corruption and mismanagement. In addition, the MOH should promote local pharmaceutical manufacturing and implement a medicine pricing containment policy to avoid abuse and prevent overexploitation of patients, increase medicine price transparency, and reduce pharmaceutical supply chain distortion. Recommended regulatory reviews include accreditation of unlicensed illegal medicine outlets to facilitate accountability, regulatory oversight, and active surveillance. The national post-market surveillance regulatory capacity should be strengthened to improve rational medicine use. A 3-year diploma course should be replaced with a shorter 1- or 2-year pharmaceutical support staff training not eligible to superintend a pharmacy. The recommended legislative review includes a mandatory clause to enforce generic prescribing and the implementation of generic substitution by health workers. Unethical manipulative pharmaceutical marketing practices should carry stiffer penalties to deter malpractice. Future research areas include investigation of medicine prescribing and dispensing practices, medicine consumption studies, medicine price differences within different health sub-sectors, and between licensed pharmacies and unlicensed illegal medicine outlets.
\end{abstract}

Keywords: substandard and falsified medicines, pharmacy practice, regulation, pharmaceutical supply chain

\section{Introduction}

Kenya is a low middle-income country in sub-Saharan Africa ${ }^{1}$ with an estimated population of 47.6 million people ${ }^{2}$ and is the regional economic and pharmaceutical hub for the East and Central African countries. ${ }^{3}$ Kenya's major healthcare priority is the control of communicable diseases; however, there is an emerging non-communicable disease burden that needs to be addressed. ${ }^{4}$ Kenya's healthcare is anchored in its Constitution, in which health is considered a fundamental human right ${ }^{5}$ implemented through the primary healthcare concept. ${ }^{4}$ Healthcare in Kenya has a devolved governance structure managed mostly at the county level but interdependent with the national government. The essential health service delivery is assigned to each of the 47 distinct county governments, ${ }^{5}$ whilst the national government is involved with the coordination and implementation of the national health policy and regulation, technical support, capacity building, and management of national health institutions and health programs. ${ }^{5-8}$

We reviewed the complex environment faced by patients in accessing their medications in Kenya. The review focussed on information and issues that affect access of medicines by patients and proposes solutions that could address 


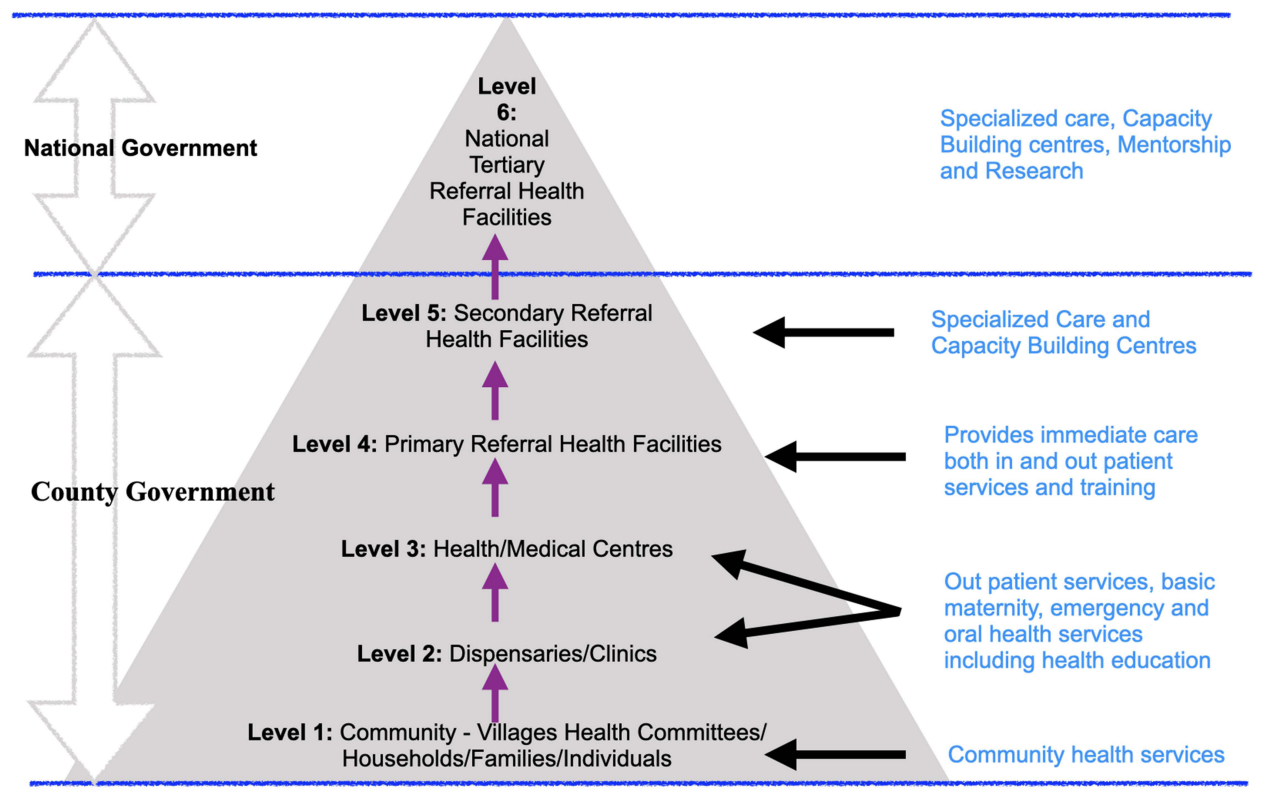

Figure I Kenya healthcare service delivery and patient referral levels. Adapted from Ministry of Health Kenya. Kenya primary health care strategy framework: 2019-2024; 2020. Available from https://www.health.go.ke/wp-content/uploads/2020/07/Kenya-Primary-Healthcare-Strategic-Framework/3-signed.pdf. ${ }^{4}$

them. We searched and reviewed literature published in English across electronic databases including PubMed, Web of Science, and Google Scholar, as well as grey literature. The search terms used during the review include "access", "Kenya", "medicines", "substandard", "falsified", and "pharmacy practice".

In general, the health sector in Kenya is divided into three main sub-sectors, namely, public, private not-for-profit, and private for-profit sub-sectors. The private sector constitutes the health sector not under direct control of the Ministry of Health $(\mathrm{MOH})$, whilst public sector means the health sector which is under direct control of the $\mathrm{MOH}$.

The public health sub-sector is currently structured into six hierarchical levels ${ }^{8}$ through an established referral system, starting with the lowest primary health facilities unit at the community (level 1) and ending at the national referral health facilities as the highest (level 6), as shown in Figure $1 .{ }^{4}$ On the other hand, the private health sector is structured mainly from the second level through to fifth level (Figure 1).

In each of the three health sub-sectors there are several different stakeholders, owned by different institutions within the sector, as shown in Table 1.

There is an uneven distribution of health facilities in Kenya with about $18 \%$ of landmass not meeting the WHO criteria for patient access ${ }^{9}$ documented in the Kenya master health facility list (KMHFL), a database showing distribution of licensed health facilities in Kenya. The database has about $48 \%$ public, $41 \%$ private for-profit, and $11 \%$ private not-for -profit health facilities. ${ }^{10}$ The database, however, does not include a list of registered licensed pharmacies. usually maintained by the Pharmacy and Poisons Board (PPB), the national medicine regulatory authority. There is no database in Kenya (both KMHFL and PPB) that has a list of illegal unlicensed health facilities, despite numerous crackdowns showing that they exist in the health sector. ${ }^{11-13}$ This review will only focus on pharmaceutical components and their impact on patient access to medicines within Kenya's health sector.

\section{Medicine Access by a Patient within Kenya's Health Sub-Sectors}

From a patient perspective, access to affordable, safe, effective, and quality-assured medicine is one of the most important determinants of healthcare quality and its delivery. Access to medicines is also an essential component of universal health coverage and good health outcomes. ${ }^{14,15}$ The World Health Organization (WHO) has defined access to medicine as a person's ability to continuously obtain an essential medicine that is available within a 1-hour walk at an 
Table I Ownership of Different Institutions within Health Sub-Sectors

\begin{tabular}{|c|c|c|}
\hline Institution Type & Ownership within Health Sub-Sectors & Example of Institution \\
\hline \multirow[t]{5}{*}{$\begin{array}{l}\text { Facilities involved with health service } \\
\text { delivery such as hospitals, health } \\
\text { centers, dispensaries, and clinics }\end{array}$} & Public though $\mathrm{MOH}$ and county governments & $\begin{array}{l}\text { Hospitals, health centers, and dispensaries } \\
\text { including their in-house pharmacies, as described } \\
\text { in Figure I }\end{array}$ \\
\hline & $\begin{array}{l}\text { Non-commercial not-for-profit owned by Faith- } \\
\text { Based Organizations (FBOs), Non-governmental } \\
\text { Organizations (NGOs) or Community Based } \\
\text { Organizations (CBOs) }\end{array}$ & $\begin{array}{l}\text { Hospitals, clinics, and nursing homes including } \\
\text { their in-house pharmacies }\end{array}$ \\
\hline & \multirow[t]{3}{*}{ Private for-profit } & $\begin{array}{l}\text { Health management and advisory/consultancies } \\
\text { agencies }\end{array}$ \\
\hline & & $\begin{array}{l}\text { Hospitals, clinics, and nursing homes including } \\
\text { their in-house pharmacies }\end{array}$ \\
\hline & & $\begin{array}{l}\text { Stand-alone retail Pharmacies including illegal } \\
\text { unlicensed facilities }\end{array}$ \\
\hline \multirow[t]{3}{*}{ Medical training institutions } & $\begin{array}{l}\text { Public autonomous health institutions or colleges or } \\
\text { Public Universities, FBOs and Private }\end{array}$ & \multirow[t]{3}{*}{ Mid-level technical colleges and Universities } \\
\hline & $\begin{array}{l}\text { Partially private colleges or Universities owned by } \\
\text { FBOs }\end{array}$ & \\
\hline & Fully commercial private colleges or Universities & \\
\hline \multirow[t]{4}{*}{$\begin{array}{l}\text { Medical product supply chain } \\
\text { agencies }\end{array}$} & $\begin{array}{l}\text { Public autonomous government agency under the } \\
\mathrm{MOH}\end{array}$ & $\begin{array}{l}\text { Kenya Medical Supplies Authority (Government of } \\
\text { Kenya, 2020b) }\end{array}$ \\
\hline & Non-commercial not-for-profit owned by FBOs & Mission for Essential Drugs and Supplies \\
\hline & \multirow[t]{2}{*}{ Private for-profit sector } & $\begin{array}{l}\text { Pharmaceutical manufacturers, medicine } \\
\text { importers, distributors, wholesale, and retail } \\
\text { pharmacies }\end{array}$ \\
\hline & & $\begin{array}{l}\text { MedSource owned by Management Sciences for } \\
\text { Health }\end{array}$ \\
\hline \multirow[t]{3}{*}{ Health financing agencies } & $\begin{array}{l}\text { Public autonomous government agency under the } \\
\mathrm{MOH}\end{array}$ & National Health Insurance Fund \\
\hline & \multirow[t]{2}{*}{ Private for-profit sector } & Private health insurance agencies \\
\hline & & $\begin{array}{l}\text { Information communication and technologies used } \\
\text { in health such as mobile health applications }\end{array}$ \\
\hline \multirow[t]{2}{*}{ Regulatory authorities } & $\begin{array}{l}\text { Public autonomous or semi-autonomous } \\
\text { government agencies under the } \mathrm{MOH}\end{array}$ & $\begin{array}{l}\text { Professional and medical product regulation and } \\
\text { quality control }\end{array}$ \\
\hline & $\begin{array}{l}\text { Public autonomous government agency not under } \\
\text { the } \mathrm{MOH}\end{array}$ & $\begin{array}{l}\text { - Insurance regulatory authority } \\
\text { - Communications Authority of Kenya }\end{array}$ \\
\hline National public health programs & $\begin{array}{l}\text { Public though } \mathrm{MOH} \text { that coordinate specific health } \\
\text { interventions or priorities as national programs or } \\
\text { divisions }\end{array}$ & $\begin{array}{l}\text { - Division of Family Health } \\
\text { - National HIV/AIDS and Sexually Transmitted } \\
\text { Infections Control program and National } \\
\text { Tuberculosis, Leprosy and Lung Disease Control } \\
\text { - Division of Malaria Control } \\
\text { - Neglected Tropical Diseases Program } \\
\text { - Division of Vaccines and Immunization } \\
\text { - Cancer Control Program }\end{array}$ \\
\hline
\end{tabular}


Table 2 Summary of Health Institutions within Kenya's Health Sector

\begin{tabular}{|c|c|c|c|c|}
\hline $\begin{array}{l}\text { Health } \\
\text { Sector }\end{array}$ & $\begin{array}{l}\text { Health Facility } \\
\text { Type }\end{array}$ & Regulatory Body & $\begin{array}{l}\text { Main } \\
\text { Professional } \\
\text { Category in the } \\
\text { Facility }\end{array}$ & $\begin{array}{l}\text { Supply Entity Facilitating Medicine Access to } \\
\text { Patients }\end{array}$ \\
\hline $\begin{array}{l}\text { Public health } \\
\text { sector }\end{array}$ & $\begin{array}{l}\text { Hospitals, Health } \\
\text { Centers and } \\
\text { Dispensaries }\end{array}$ & $\begin{array}{l}\text { All regulatory } \\
\text { authorities under } \\
\mathrm{MOH}\end{array}$ & $\begin{array}{l}\text { All health } \\
\text { professional } \\
\text { category }\end{array}$ & $\begin{array}{l}\text { Public procurement agency (Kenya Medical Supplies } \\
\text { Authority [KEMSA]) }\end{array}$ \\
\hline $\begin{array}{l}\text { Private not- } \\
\text { for-profit } \\
\text { health sector }\end{array}$ & $\begin{array}{l}\text { Hospitals, Health } \\
\text { Centers, } \\
\text { Dispensaries, and } \\
\text { Clinics }\end{array}$ & $\begin{array}{l}\text { Kenya Medical } \\
\text { Practitioners and } \\
\text { Dentists Council }\end{array}$ & $\begin{array}{l}\text { All health } \\
\text { professional } \\
\text { category }\end{array}$ & $\begin{array}{l}\text { Private procurement agency (Mission for Essential Drugs and } \\
\text { Supplies [MEDS]) and private pharmacies wholesalers, } \\
\text { importers, distributors, or local manufacturers }\end{array}$ \\
\hline \multirow[t]{7}{*}{$\begin{array}{l}\text { Private for- } \\
\text { profit health } \\
\text { sector }\end{array}$} & $\begin{array}{l}\text { Private Hospitals and } \\
\text { Medical Centers }\end{array}$ & $\begin{array}{l}\text { Kenya Medical } \\
\text { Practitioners and } \\
\text { Dentists Council }\end{array}$ & $\begin{array}{l}\text { Medical Officers, } \\
\text { Dentists and } \\
\text { Pharmacists }\end{array}$ & \multirow[t]{6}{*}{$\begin{array}{l}\text { Private pharmacies wholesalers, importers, distributors or } \\
\text { local manufacturers, medicine pilferage from sources above }\end{array}$} \\
\hline & \multirow[t]{3}{*}{ Private Clinics } & $\begin{array}{l}\text { Kenya Medical } \\
\text { Practitioners and } \\
\text { Dentists Council }\end{array}$ & $\begin{array}{l}\text { Medical Officers } \\
\text { and Dentists }\end{array}$ & \\
\hline & & $\begin{array}{l}\text { Clinical Officers } \\
\text { Council }\end{array}$ & Clinical officers & \\
\hline & & $\begin{array}{l}\text { Nursing Council of } \\
\text { Kenya }\end{array}$ & Nurses & \\
\hline & $\begin{array}{l}\text { Wholesale } \\
\text { Pharmacies }\end{array}$ & \multirow[t]{2}{*}{$\begin{array}{l}\text { Pharmacy and } \\
\text { Poisons Board }\end{array}$} & Pharmacists & \\
\hline & Retail Pharmacies & & $\begin{array}{l}\text { Pharmacists and } \\
\text { Pharmaceutical } \\
\text { Technologists }\end{array}$ & \\
\hline & $\begin{array}{l}\text { Illegal health facilities } \\
\text { including those in } \\
\text { informal sector }\end{array}$ & $\begin{array}{l}\text { All regulatory } \\
\text { authorities }\end{array}$ & Quacks & $\begin{array}{l}\text { Medicine pilferage from sources above, private pharmacies } \\
\text { wholesalers, importers, distributors, or briefcase suppliers }\end{array}$ \\
\hline
\end{tabular}

affordable price from either a health facility or a medicine outlet. ${ }^{16}$ In most instances, Kenyan patients access their medicines from a prescription dispensed from a pharmacy/chemist within a health facility, ${ }^{17}$ whether licensed or not licensed. In Kenya, the word "pharmacy" is commonly used interchangeably with the word "chemist" to define a retail health facility, outlet, or shop where a medicine can be accessed by a patient when compounded, dispensed, or purchased as part of community pharmacy practice. However, there are some cases where a patient self-medicates over the counter without a prescription, despite the risks associated, such as increased anti-microbial resistance, inaccurate diagnosis, inappropriate use of medicines, differing care from a health worker, concealment of serious disease symptoms, and drug abuse or dependence. ${ }^{18-20}$ Medicines dispensed to patients are usually supplied from institutions, as summarized in Table 2.

The pharmaceutical sector in Kenya is uncoordinated, highly fragmented, and majorly driven by competition involving local and foreign pharmaceutical manufacturers, importers, warehousing agencies, distributors, wholesale pharmacies, and retail pharmacies/chemists. The pharmaceutical institutions in the private health sub-sector supply medicines to both the public health sub-sector (through the Kenya Medical Supplies Authority (KEMSA)) and not-forprofit health sub-sector (through the Mission for Essential Drugs and Supplies (MEDS)). ${ }^{21}$ Medicine quality assurance is 
regulated through pre-market approval and post-market surveillance by the PPB supported by testing from several quality control laboratories (QCL) such as the PPB-QCL, national quality control laboratory (NQCL), Mission for Essential Drugs and Supplies (MEDS-QCL), and Kenya Medical Supplies Authority (KEMSA-QCL). NQCL and MEDS-QCL are laboratories that have been accredited by the WHO. ${ }^{22}$

The commonly prescribed medicines to patients remain unknown; however, this can be inferred from data of medicine imported into Kenya. Unpublished reports from PPB show that $50 \%$ of the medicine market share is controlled by anti-infectives, immunological and cardiovascular agents. ${ }^{23}$ So far, the most dispensed medicines are also unknown apart from a study by Godman et al 2018, which showed that the commonly dispensed antibiotics from pharmacies are penicillins (over 50\%), cephalosporins (12.6\%), and fluoroquinolones $(11.7 \%) .{ }^{19}$ Kenya imports over $70 \%$ of medicines from India (37\%), Europe (20\%), China (9\%), the US (6\%), and South Africa (4\%), ${ }^{23}$ with about $28 \%$ being locally produced. ${ }^{24}$ Overreliance on imported medicines in Kenya increases medicine inaccessibility, pharmaceutical supply chain disruption, and unpredictable medicine pricing to patients, as demonstrated during the current COVID-19 global pandemic. ${ }^{25,26}$ Though the Government of Kenya has an agenda to promote local pharmaceutical manufacturing, through its "big four agenda", ${ }^{27}$ there still needs to be harmonized policy coherence and an adequate financing model that can spur the industry into self-reliance and ensure medical product security. ${ }^{24}$

Medicine procurement in the Kenya public health sub-sector is mainly through KEMSA, a state corporation established under the Laws of Kenya, the KEMSA Act of $2013 .{ }^{28}$ "Procurement" in this context is defined broadly as a set of processes taken to order and purchase a medicine by any health facility, including its distribution throughout the supply chain. Medicine procurement at KEMSA is governed by the KEMSA Act, the Public Procurement and Asset Disposal Act of 2015, and MOH procurement guidelines. ${ }^{29}$ KEMSA procures medicines using funds from national and county governments and donors. ${ }^{30}$ All the 47 county departments of health have a legal obligation to preferentially procure all their essential generic medicines from KEMSA. Once a medicine has been procured by a Kenya public health facility, it is stored in the drug stores, until it is requisitioned by the pharmacy unit of the public health facility and dispensed to a patient. The patient may access the medicine either free of charge or at a subsidized $\operatorname{cost}^{17}$ from an outpatient or inpatient pharmacy within a health facility. On average most county health facilities procure $70 \%$ of their medicines from KEMSA, 28\% from MEDS, and 2\% from private for-profit distributors. ${ }^{31}$ Although KEMSA is the first point of procurement call, some public health facilities also order items from MEDS and other private suppliers. An unpublished report from the Ethics and Anticorruption commission indicates that some counties still procure medicines from outside the KEMSA or MEDS system. ${ }^{32}$ Currently, KEMSA is battling with corruption on the procurement of Coronavirus Disease 2019 (COVID-19) related medical products. ${ }^{33,34}$ This indicates that the current public procurement needs to be strengthened to cushion it from corruption and mismanagement. ${ }^{8}$

Medicine procurement in the private not-for-profit health sub-sector, especially many faith-based organizations, is mainly through MEDS, a Christian not-for-profit agency. ${ }^{21,31,35}$ Medicine procurement in the NGO health sub-sector, such as Médecins Sans Frontières, the Red Cross, and other humanitarian organizations, is done through a multi-country pooled procurement system to bypass the national procurement system due to their mistrust in national procurement systems. ${ }^{36}$ This means that medicines procured in the NGO sub-sector do not undergo pre-market approval from PPB but gain entry to the country as donations. Some NGOs also source their medicines from local private suppliers, such as MEDS or directly from private for-profit importers, local manufacturers, distributors, or retail pharmacies. Medicines in the not-for-profit health sub-sector are then usually accessed by patients free-of-charge or at a subsidized cost from the pharmacy unit within a health facility.

\section{Main Factors Affecting Medicines Access for a Patient in Kenya}

The main factors that affect patient access to essential medicines in Kenya are stockouts or unavailability and unaffordability. ${ }^{37,38}$ An essential medicine is determined as one that satisfies priority healthcare needs of the populace, usually selected based upon evidential safety, efficacy, public health importance, and cost-effectiveness. ${ }^{15}$ In addition, a patient should easily access the medicine from a functional health facility that is supplied in a suitable dosage form in a sufficient amount at an affordable price. ${ }^{39}$ There is considerable evidence that essential medicines, especially for the management of non-communicable diseases in Kenya, are still not readily available to patients within the public health 
Table 3 Medicine Percentage Societal Price Mark-Up in Kenya's Supply Chain

\begin{tabular}{|l|l|}
\hline Supply Level & Profit Mark-Up \\
\hline Local manufacturer & $10-15 \%$ \\
\hline Distributor/Wholesaler & $10-15 \%$ \\
\hline Retail Pharmacy & $25-33 \%^{30}$ \\
\hline Foreign manufacturer & Unknown \\
\hline Importer/Warehousing Agencies & Unknown \\
\hline
\end{tabular}

sector in comparison to the private (both for-and not-for-profit) health sectors. ${ }^{40}$ The average availability of essential medicines in public health facilities in $2018 / 9$ was about $44 \%$, in comparison to $72.4 \%$ in the private health facilities. ${ }^{41,42}$ The absence of essential medicines can lead to underuse, lack of satisfaction of care, and distrust of public healthcare facilities. ${ }^{43-45}$ Lack of medicines in the public health sub-sector also causes an increased demand for medicine related out-of-pocket (OOP) expenditure from the private health sector that may thus increase a likelihood for a patient to purchase a substandard and falsified (SF) medicine from the private market that includes unlicensed and illegal pharmacies, medicine outlets, or unregulated websites. A "substandard medicine" is defined by the WHO as an authorized and legitimately available medicine that fails to meet either their quality requirements or standards, or both. ${ }^{46}$ A substandard medicine may arise from unintentional manufacturing errors and negligence, venality in procurement and regulation, or poor manufacturing and distribution practices. ${ }^{47,48}$ On one hand, a "falsified medicine" refers to a medicine that is intentionally and fraudulently or deliberately misrepresented with respect to its identity, composition, or source. ${ }^{46} \mathrm{SF}$ medications when taken by a patient pose a serious health risk to not only the patient but also a risk to the public because it undermines health systems. SF medications may lead to drug resistance, thereby complicating management of infectious diseases and difficulty in monitoring and management of chronic diseases. ${ }^{49-51}$ This may lead to poor health outcomes, increased morbidity, and mortality. ${ }^{47}$ In addition, drug resistance may lead to poor patient adherence to therapy and excessive prescribing of antimicrobials to patients by healthcare workers. ${ }^{52}$

Purchase of medicines by a patient in Kenya varies within the public and private health sub-sectors because of the difference in medicine pricing structure and lack of regulation. ${ }^{8}$ Medicine pricing surveys conducted in Kenya have demonstrated that medicine prices in the public and private not-for-profit health sub-sector are competitively lower in comparison to international reference prices, thus making them affordable to patients. ${ }^{8,53}$ The better medicine pricing in public and private not-for-profit health sub-sectors is due to competitive bidding processes. Thus, poor patients easily access medicines from public and the private not-for-profit health sub-sectors. On the other hand, medicine pricing in the private for-profit healthcare sector is guided by a free-market policy using an informal non-binding and non-enforceable societal price mark-up, not anchored in any legislation, ${ }^{54}$ as summarized in Table 3 .

A study by Health Action International, in 2018, found that the median mark-up to a patient in the private for-profit health sub-sector exceeded the official acceptable price mark-up and procurement prices found in public and private notfor-profit healthcare sectors. ${ }^{53}$ The medicine price mark-up rule encourages maximization of profits with no medicine price containment policy. ${ }^{54}$ This may lead to some unscrupulous wholesalers and distributors blurring and distorting pharmaceutical supply chain boundaries to sale medicines directly to a patient, as depicted in Figure $2 .{ }^{54}$ Additionally, some wholesalers and distributors may engage in corrupt behaviours that facilitate medicine pilferage from established health facilities, which may lead to medicine stock-outs and shortages. ${ }^{55-58}$ This may provide an avenue to allow entry of medicines from unknown sources into the legitimate supply chain..$^{59,60}$

Patients visiting private for-profit health facilities are poor and search for the lowest possible medicine price. However, such poor patients are often exploited and not protected from inappropriate medicine price increases. Despite anecdotal evidence of medicine price differences between different private for-profit licensed or unlicensed illegal pharmacies, there is no study that has determined the extent of the impact to patient access to medicines. Kenya's 


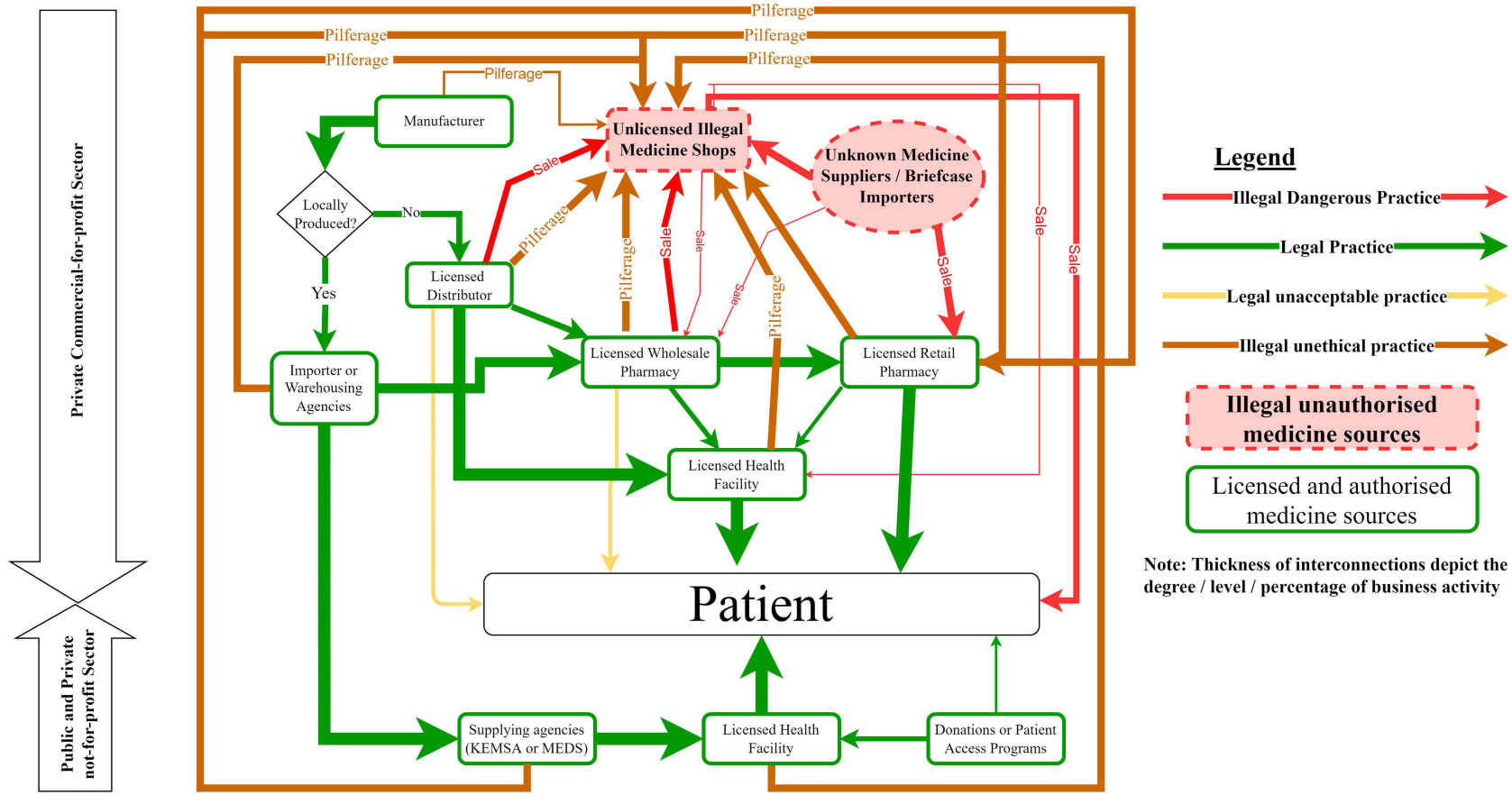

Figure 2 Medicine supply chain in Kenya.

private for-profit health sub-sector needs to be anchored with a medicine pricing containment policy, price negotiation between government and industry, price transparency and monitoring, ${ }^{61}$ and avoid patient over-exploitation and abuse of free pharmaceutical market economy.

\section{Patient Access and Medicine Financing in Kenya}

Kenya lacks a functional universal health financing system. ${ }^{62}$ Health financing mainly depends on high OOP expenditure and indirect taxation from the National Health Insurance Fund (NHIF), private health insurance, employer medical schemes, and subsidies from donors, NGOs, and community-based health financing schemes. ${ }^{44}$ The estimated population in Kenya covered by insurance is estimated to be $19 \% .{ }^{8,63}$ The rate of insurance coverage is higher among the urban population (27\%) in comparison to the rural population, which is about $14 \%{ }^{44,64}$ The high OOP expenditure on health creates an inequitable barrier to patients' access to health services, including access to medicines. ${ }^{62}$ The proportion of total health expenditure attributable to cost of medicines such as OOP is about $13 \%{ }^{8}$ The main determinants of medicine-related OOP expenditure in Kenya include the socioeconomic status of the household and presence of an elderly, disabled hospitalized family dependent with a chronic illness. ${ }^{65-67}$ To avoid catastrophic health expenditure, the $\mathrm{MOH}$ with support from donors and partners has subsidized financing of basic health services by making medicines more affordable within the public health sub-sector and private not-for-profit. A patient can therefore access essential generic medicines used for the prevention and treatment of most infectious diseases, such as malaria, HIV/AIDs, tuberculosis, and those used in reproductive, maternal, and child health conditions free-of-charge or at a subsidized cost. ${ }^{6}$ However, most medicines, especially those used to manage critical non-communicable diseases such as cancer, diabetes mellitus, and hypertension, as well as medicines used for the treatment of multi-drug resistant infectious diseases, are still unavailable, inaccessible, and unaffordable to the majority of patients. ${ }^{54,68-70}$ It is estimated by the MOH that about $38 \%$ use catastrophic health expenditure to pay for their medical bills and about $16 \%$ of patients avoid seeking care because of financial constraints. ${ }^{71}$ To alleviate suffering in such patients, some pharmaceutical companies have developed access programs aimed at reducing patient exploitation and securing the supply chain from SF medicines to the underserved poor populations. ${ }^{72-74}$ However, the impact and sustainability of medicine access programs in Kenya has not shown any impact in increasing access and reducing medicines prices in Kenya. It would be beneficial if the MOH would 
develop an accurate system that could be used to track pharmaceutical commodity expenditure from both private and public health sectors; disaggregated by type of medicines dispensed, sold, or procured and their degree of access to specific patients with the aim of reducing medicine-related OOP costs. ${ }^{75,76}$

\section{Patient Medicine Access and Pharmacy Practice in Kenya}

Pharmacy practice in Kenya is governed by sessional paper Number 4 of 2012, the Kenya National Pharmaceutical Policy (KNPP - 2012). This policy was developed by the pharmaceutical services unit of the $\mathrm{MOH}^{16}$ and strengthened by legislation, the Pharmacy and Poisons Act, Chapter 244 of 1957, Laws of Kenya (CAP 244). ${ }^{77}$ The goal of KNPP 2012 and CAP 244 is universal access to quality assured, safe, and effective essential medicines and pharmaceutical services. Unlike other countries where regulation of the profession of pharmacy has been separated from regulation of medical products, CAP 244 regulates both the pharmacy profession and the manufacture, supply, sale, and distribution of medicines. ${ }^{77}$ CAP 244 mandates the PPB to regulate pharmacy practice and issue licenses for a pharmacy or a chemist in Kenya based on the legal requirements. ${ }^{77}$ A Kenya household health expenditure and utilization survey conducted in 2014 found that about $23 \%$ of all outpatient visits were to a pharmacy or clinic with a pharmacy. ${ }^{6}$ Wafula et al ${ }^{78}$ found that patients often first visit a retail pharmacy for self-medication before they visit a hospital. For a pharmacy to be licensed, it must be either fully owned or be superintended by either a pharmacist or a pharmaceutical technologist (ptechs), formerly called pharmaceutical technicians before a legislative amendment enacted in $2002 .{ }^{77}$ Pharmacists are university graduate degree holders in Pharmacy, while ptechs are holders of a diploma in either pharmacy or pharmaceutical technology. ${ }^{17,79}$ Ideally a patient should access their medicines from the two pharmacy professional categories, pharmacist and ptechs based on medicine schedule requirements set by PPB, which are summarized in Table 4. The medicine schedule defines the required health professional authorized to prescribe or dispense a particular medicine to a patient. ${ }^{80}$ In principal and legally, the role of a ptech is mainly dispensing to a patient and inventory management under supervision of a pharmacist. However, in real practice, ptechs tend to play a similar competing role and often deliberately misrepresent themselves to patients as pharmacists ${ }^{81,82}$ despite the current medicine schedule requirements. This has made many ptechs to superintend and own the majority of licensed retail pharmacies without direct supervision of a pharmacist. ${ }^{17,79}$ The misrepresentation practice by ptechs poses a huge risk to patients' access to medicines because they do not have the requisite professional training to allow them to independently administer medicines to patients without the supervision of a pharmacist. This paper proposes the 3-year diploma in pharmacy or pharmaceutical technology course ${ }^{79}$ currently undertaken by ptechs be replaced with a 1- or 2-year pharmaceutical support staff training

Table 4 Current Medicine Scheduling System in Kenya ${ }^{80}$

\begin{tabular}{|c|c|c|c|}
\hline $\begin{array}{l}\text { Part } \\
\text { Number }\end{array}$ & Schedule Number & Prescribing Health Professional Category & Dispensing Professional Category \\
\hline \multirow[t]{2}{*}{$\begin{array}{l}\text { Part } \\
\text { I Poisons }\end{array}$} & $\begin{array}{l}\text { Schedule I - Prescription Only } \\
\text { Medicine (POM) }\end{array}$ & \multirow{2}{*}{$\begin{array}{l}\text { Prescription from Registered Medical } \\
\text { Practitioner, Dentist, or Veterinary Surgeon and } \\
\text { in limited quantities without prescription by } \\
\text { a registered pharmacist }\end{array}$} & Registered pharmacist \\
\hline & $\begin{array}{l}\text { Schedule II - Pharmacy Only } \\
\text { Medicines }(\mathrm{P}) \text { - Prescription } \\
\text { from an authorized prescriber is } \\
\text { required }\end{array}$ & & $\begin{array}{l}\text { Prescribing health professional categories } \\
\text { under Part I may stock and dispense } \\
\text { emergency medicines to be used during their } \\
\text { medical practice }\end{array}$ \\
\hline \multirow[t]{3}{*}{$\begin{array}{l}\text { Part II } \\
\text { Poisons }\end{array}$} & \multirow[t]{2}{*}{ Schedule III } & $\begin{array}{l}\text { Prescription from any authorized prescriber } \\
\text { above }\end{array}$ & $\begin{array}{l}\text { Enrolled ptech under supervision of } \\
\text { a registered pharmacist }\end{array}$ \\
\hline & & Not required & Registered pharmacist \\
\hline & $\begin{array}{l}\text { Schedule IV - Over the Counter } \\
\text { Medicines (OTC) }\end{array}$ & Not required & $\begin{array}{l}\text { Authorized medicine outlets and } \\
\text { supermarkets/shops }\end{array}$ \\
\hline
\end{tabular}

Note: Data from Ministry of Health Kenya. ${ }^{80}$ 
not eligible to independently superintend a pharmacy without the presence of a pharmacist. In addition, this paper also proposes updating of the current medicine schedule in Kenya (Table 4) by the PPB to enable effective enforcement of pharmacy practice rules and protection of patients from accessing medicines from unauthorized personnel.

Apart from the above two recognized pharmacy professional categories, patients also access medicines from other untrained personnel working either in a licensed pharmacy, as support staff, or from an illegal medicine outlet. The untrained persons are usually employed as pharmacy assistants, nurses, nursing assistants, or other support staff such as cleaners or messengers in a legally registered health facility or pharmacy. Such untrained personnel learn the art of medicine dispensing and transcription of prescriptions from a licensed health facility or pharmacy due to task shifting practices often practiced by ptechs and pharmacists. ${ }^{83}$ However, after either retirement, redundancy, or resignation they feel that have gained "enough experience" to operate their own unlicensed retail medicine outlet. ${ }^{83}$ Wafula et al, ${ }^{79}$ in an earlier study, documented the presence of illegal unlicensed retail medicine outlets. A poor patient especially those in the informal sector and slum dwelling areas, faces a lot of challenges in accessing quality health services. About $15 \%$ of such patients rely on such illegal unlicensed retail medicine outlets for their primary healthcare needs. ${ }^{6}$ The International Labour Organization defines the informal sector as an "unincorporated enterprise owned by a household that operates as a low level of organisation, with little or no division of capital and labour, as factors of production and has a primary objective of generating employment and incomes to the person concerned". ${ }^{84}$ Most poor patients obtain medicine related information or advice on their health condition from either a neighbour or relative who had a similar health condition in the past. This often leads to self-diagnosis or self-medication from the nearest health facility or pharmacy. ${ }^{18-20}$

Wafula et al, ${ }^{78}$ documented that most of the illegal retail medicine outlets neither have a refrigerator nor a separate dispensing area. The untrained staff manning such illegal medicine outlets do not have the requisite pharmaceutical training and are unaware of the law governing pharmacy practice. This makes many unregistered and illegal medicine outlets practice unethical activities, such as misdiagnosis and dispensing or selling medicines without a prescription. Such practices may potentially allow entry of SF, degraded, or expired medicines into the formal pharmaceutical supply chain because of their unethical procurement practices. This may compromise the quality of pharmaceutical care and may endanger patients' lives. The PPB has, without success on several occasions, through expensive crackdowns exercises, tried eradicating illegal medicine outlets that do not comply with regulations. ${ }^{11,12}$ The current measures employed by the PPB such as closure of illegal medicine outlets and seizure of medicines ${ }^{11,12}$ has not been effective and requires a more effective system. This paper is proposing for the PPB to consider accrediting current unlicensed medicine outlets and encourage self-regulation as a means of protecting patients, especially in rural or peri-urban areas. Such a system would provide a regulatory oversight and allow active surveillance and accountability rather than the never-ending expensive "cat and mouse" regulatory crackdowns with unlicensed medicine sellers.

Unethical business practices, especially facilitated by pharmaceutical or medical representatives (Med Reps), also promote irrational prescribing, dispensing, and use of medicines and unfair competition in the pharmaceutical sector. Such practices include unethically gifting or pay-rolling a healthcare worker whenever a particular medicine brand is being prescribed or dispensed. ${ }^{83}$ In some instances, Med Reps even collude with prescribers to have a statement, "do not substitute" included as a footnote on personalized prescription pads offered to them as gifts. Such unethical practices may induce prescribers to "force" patients to procure specific brands of medicines without due consideration of their cost and quality. The prescribers may also end up prescribing medicines that have not been authorized by the PPB, which poses a risk to patients, especially when there is a shortage in supply and increased demand for such medicines. This will provide an opportunity for unscrupulous importers to introduce SF medicines into the legitimate pharmaceutical supply chain in addition to also creating an extra and unnecessary regulatory burden. Even though PPB has developed guidelines to prohibit misleading, inaccurate, non-factual, unfair, non-objective, and unethical information from being advertised, promoted, or communicated to healthcare practitioners and the public by Med Reps, this malpractice remains rampant. ${ }^{85}$ There is a need to enact legislative reforms to make it mandatory for healthcare providers in the public sector to prescribe medicines using the generic name rather than the branded name. ${ }^{83}$ In addition, a law should be enacted to empower pharmacists to implement generic substitution ${ }^{86,87}$ and explicitly prohibit unethical manipulative marketing practices with stiffer penalties. 
Another emerging phenomenon is purchase over the internet where there are few legally licensed pharmacies that have an online portal to allow ordering of both OTC and prescription medicines. Such pharmacies are currently licensed after verification of their physical existence and the qualification of pharmaceutical personnel running it. So far there is no study conducted to understand the quantity and quality of the medicines sourced by patients via the internet in Kenya. Though the sale of medicines over the internet may offer some benefits such as improved patient access to medicines convenience, cost savings ${ }^{88}$ and facilitating traceability and transparency of medicines ${ }^{89}$ the current CAP 244 does not have a provision to facilitate proper regulatory oversight of online pharmacies. This is because online pharmacies provide a convenient and easy way to access medicines by patients who may obtain SF medicines from criminals ${ }^{88,90-92}$ and sale of medicines without a valid prescription. ${ }^{89} \mathrm{PPB}$ needs to strengthen a system to regulate online pharmacies that can facilitate verification of trusted online pharmacy websites. ${ }^{90,93}$

\section{Conclusion}

For Kenya's healthcare system to effectively take control of the communicable and non-communicable disease burden as enshrined in the Constitution, the patient access to medicines needs to be improved. There is a critical need to increase access to medicines to patients in Kenya without compromising the quality, safety, and efficacy of medicines that require urgent regulatory attention and legislative-policy interventions. Efforts should be made to increase medicine availability in the public health sector, since this increases the demand for medicines in the vulnerable private sector which may be infiltrated with SF medicines. Despite the several amendments to CAP 244, the law that provides the current regulatory framework, a total overhaul is urgently required to make it relevant and effective in the control of the current pharmaceutical practice and the vibrant pharmaceutical sector in Kenya. Particular attention should be focused on strengthening the regulatory capacity of $\mathrm{PPB}$, especially on its post-market surveillance efforts to restrict the entry of SF medicines into the legitimate pharmaceutical supply chain. To assure patient safety, there is a need for PPB to update its medicine scheduling system that should form a basis for enforcement and control of medicines in the market to ensure medicine rational use. In addition, the current 3-year diploma in pharmacy or pharmaceutical technology course with a 1or 2-year pharmaceutical support staff training not eligible to independently superintend a pharmacy without the presence of a pharmacist. The PPB should consider accreditation of unlicensed medicine outlets to encourage self-regulation and provide for an appropriate regulatory oversight, active surveillance, and accountability in place of the never ending and expensive "cat and mouse" regulatory crackdowns with unlicensed medicine sellers. There is also a need to enact legislative reforms to make it mandatory for healthcare providers in the public sector to prescribe medicines using the generic name rather than the branded name. ${ }^{83}$ In addition, a law should be enacted to empower pharmacists to implement generic substitution ${ }^{86,87}$ and explicitly prohibit unethical manipulative marketing practices with stiffer deterrent penalties.

Kenya's government should develop a medicine pricing containment policy implemented through a legal framework to avoid abuse of free pharmaceutical market economy, prevent overexploitation of patients, increase medicine price transparency. This will facilitate price monitoring and reduce pharmaceutical supply chain distortion and unethical medicine promotion practices, especially in the private sector. More research is required to investigate medicine prescribing and dispensing practices, medicine consumption studies, medicine price differences between different health sub-sectors, and medicine price comparisons between licensed pharmacies and unlicensed illegal medicine drug shops in Kenya. The efforts by the Government of Kenya on the promotion of local pharmaceutical manufacturing ${ }^{27}$ should be encouraged and strengthened through harmonized policy coherence among ministries to avoid the devastating impact of pharmaceutical supply chain disruption as experienced during the current COVID-19 global pandemic. ${ }^{25,26}$

\section{Disclosure}

Anthony Martin Toroitich is a part-time an international student $\mathrm{PhD}$ at De Montfort University, UK on study leave at the Pharmacy and Poisons Board and a part-time pharmaceutical specialist at the Intergovernmental Authority on development. The authors report no other conflicts of interest in this review. 


\section{References}

1. The World Bank Group. World bank statistics on Kenya. The World Bank Group; 2021. Available from: https://ata.worldbank.org/country/KE. Accessed May 24, 2021.

2. Kenya National Bureau of Statistics. 2019 Kenya population and housing census volume i: population by County and Sub-County; 2019. Available from: https://www.knbs.or.ke/?wpdmpro=2019-kenya-population-and-housing-census-volume-i-population-by-county-and-sub-county. Accessed May 24, 2021.

3. The Global Fund. Audit report global fund grants to the Republic of Kenya; 2018. Available from: https://www.theglobalfund.org/media/8062/oig gf-oig-18-021_report_en.pdf. Accessed May 24, 2021.

4. Ministry of Health Kenya. Kenya primary health care strategy framework: 2019-2024; 2020. Available from: https://www.health.go.ke/wp-content /uploads/2020/07/Kenya-Primary-Healthcare-Strategic-Framework13-signed.pdf. Accessed June 20, 2021.

5. Government of Kenya. The constitution of Kenya; 2010. Available from: http://www.kenyalaw.org:8181/exist/kenyalex/actview.xql?actid= Const2010. Accessed July 02, 2021.

6. Ministry of Health Kenya. Kenya household health expenditure and utilisation survey (KHHEUS); 2018. Available from: https://statistics.knbs.or. ke/nada/index.php/catalog/56. Accessed October 02, 2021.

7. Mugo P, Onsomu E, Munga B, et al. An assessment of healthcare delivery in Kenya under the devolved system; 2018. Available from: http:// repository.kippra.or.ke:8080/xmlui/bitstream/handle/123456789/2095/an-assessment-of-healthcare-delivery-in-kenya-under-The-devolved-systemsp19.pdf? sequence=1\&isAllowed=y. Accessed May 24, 2021.

8. Ministry of Health. Health products and technologies supply chain strategy 2020-2025; 2020. Available from: https://www.health.go.ke/wp-content /uploads/2020/12/HPT-Supply-Chain-Strategy-2020-2025.pdf. Accessed August 30, 2021.

9. Davis EC, Menser T, Cerda Juarez A, et al. Examining healthcare systems: a market analysis for Kenya. Eur J Train Dev. 2019;43(1-2):2-20. doi:10.1108/EJTD-06-2016-0041

10. Ministry of Health Kenya. Kenya master health facility list: find all the health facilities in Kenya; 2021. Available from: http://kmhfl.health.go.ke/ \#/facility_filter/results. Accessed May 24, 2021.

11. Pharmacy and Poisons Board. Facebook update on the crackdowns conducted by the pharmacy and poisons board (@pharmacyboardkenya); 2020. Available from: https://web.facebook.com/pharmacyboardkenya. Accessed May 21, 2020.

12. Pharmacy and Poisons Board. Twitter update on the crackdowns conducted by the pharmacy and poisons board (@ppbkenya); 2020. Available from: https://twitter.com/ppbkenya/status/1395665751881748481. Accessed May 21, 2020.

13. Mogoatlhe L. There are over 9000 clinics in Kenya's Nairobi County. only 1079 are legal. Global Citizen; 2019. Available from: https://www. globalcitizen.org/en/content/kenya-illegal-health-clinics-nairobi-country/. Accessed August 23, 2021.

14. The World Health Organization. Roadmap for access to medicines, vaccines and health product 2019-2023. Comprehensive support for access to medicines, vaccines and other health products; 2019. Available from: https://apps.who.int/iris/bitstream/handle/10665/330145/9789241517034-eng. pdf? sequence=1\&isAllowed=y. Accessed August 23, 2021.

15. The World Health Organization. Essential medicines. Geneva, Switzerland; 2016. Available from: https://www.who.int/medicines/areas/coordina tion/English_Glossary.pdf. Accessed May 30, 2021.

16. The World Health Organization. Monitoring the building blocks of health systems: a handbook of indicators and their measurement strategies. Geneva, Switzerland; 2010. Available from: https://apps.who.int/iris/bitstream/handle/10665/258734/9789241564052-eng.pdf?sequence= 1\&isAllowed=y. Accessed May 30, 2021.

17. Aywak D, Jaguga CDP, Nkonge NG, et al. Pharmacy practice in Kenya. Can J Hosp Pharm. 2017;70(6):456-462. doi:10.4212/cjhp.v70i6.1713

18. Siyoi F. Avoid self - medication pharmacy and poisons board; 2018. Available from: https://www.pharmacyboardkenya.org/blog/2017/12/avoidself-medication. Accessed August 22, 2021.

19. Godman B, Mukokinya MA, Opanga S, et al. Dispensing of antimicrobials in Kenya: a cross-sectional pilot study and its implications. $J$ Res Pharm Pract. 2018;7(2):77. doi:10.4103/jrpp.JRPP_17_88

20. Muloi D, Fevre EM, Bettridge J, et al. A cross-sectional survey of practices and knowledge among antibiotic retailers in Nairobi, Kenya. $J$ Glob Health. 2019;9(2). doi:10.7189/jogh.09.020412

21. Mission for Essential Drugs, Supplies. About us - mission for essential drugs and supplies (MEDS). Nairobi. Kenya; 2021. Available from: www. meds.or.ke. Accessed August 22, 2021

22. The World Health Organization. Medicines quality control laboratories; 2021. Available from: https://extranet.who.int/pqweb/medicines/medicinesquality-control-laboratories-list. Accessed August 22, 2021.

23. Pharmacy and Poisons Board. Trade affairs department: unpublished annual statistics 2019; 2019.

24. Wanyanga WO, Vugigi SK, Keter FK Pharmaceutical partnerships for increased access to quality essential medicines in the East Africa region; 2020. Available from: https://idl-bnc-idrc.dspacedirect.org/bitstream/handle/10625/59578/59713.pdf?sequence=1\&isAllowed=y. Accessed August $22,2021$.

25. Uwizeyimana T, Hashim HT, Kabakambira JD, et al. Drug supply situation in Rwanda during COVID-19: issues, efforts and challenges. $J$ Pharm Policy Pract. 2021;14(1):12. doi:10.1186/s40545-021-00301-2

26. Emmanuel AN, Chinelo JO, Chima MA, et al. Impact of the COVID-19 pandemic on consumers' access to essential medicines in Nigeria. Am J Trop Med Hyg. 2020;103(4):1630-1634. doi:10.4269/ajtmh.20-0838

27. Government of Kenya. The big 4 - empowering The Nation. Nairobi, Kenya; 2017. Available from: https://big4.delivery.go.ke/. Accessed May 24, 2021.

28. National Council for Law Reporting (Kenya Law Reports). The Kenya medical supplies authority Act No. 20 of $2013 ; 2013$.

29. Ministry of Health Kenya. Guidelines on management of health products and technologies in Kenya. Nairobi, Kenya; 2020. Available from: https:// www.health.go.ke/wp-content/uploads/2021/04/Guidelines-on-Management-of-HPTs-in-Kenya.pdf. Accessed May 10, 2021.

30. Mwangi J. Kenya - country commercial guide: healthcare - medical devices. International Trade Administration; 2021.

31. Mulaki A, Muchiri S. Kenya Health System Assessment. Washington, DC: Palladium Health Policy Plus; 2019:208-209.

32. Ethics and Anti-Corruption Commission Kenya. Report on the review of the systems, policies, procedures and practices in the pricing of pharmaceutical and non-pharmaceutical supplies in Kenya Public Health Sector. Government of Kenya; 2018. 
33. Igunza E Coronavirus corruption in Kenya: officials and businesspeople targeted. British Broadcasting Corporation; 2020. Available from: https:// www.bbc.com/news/world-africa-54278417. Accessed May 10, 2021.

34. Otieno B. Kemsa go, walk in and walk out with fat tender worth millions. The Standard; 2021. Available from: https://www.standardmedia.co.ke/ politics/article/2001401865/kemsa-go-walk-in-and-walk-out-with-fat-tender-worth-millions. Accessed May $10,2021$.

35. Mackintosh M, Tibandebage P, Karimi NM, et al. Rethinking health sector procurement as developmental linkages in East Africa. Soc Sci Med. 2018;200:182-189. doi:10.1016/j.socscimed.2018.01.008

36. Huff-Rousselle M. The logical underpinnings and benefits of pooled pharmaceutical procurement: a pragmatic role for our public institutions? Soc Sci Med. 2012;75(9):1572-1580. doi:10.1016/j.socscimed.2012.05.044

37. Ng G, Raskin E, Wirtz VJ, et al. Coping with access barriers to non-communicable disease medicines: qualitative patient interviews in eight counties in Kenya. BMC Health Serv Res. 2021;21(1):417. doi:10.1186/s12913-021-06433-0

38. Onyango MA, Vian T, Hirsch I, et al. Perceptions of Kenyan adults on access to medicines for non-communicable diseases: a qualitative study. PLoS One. 2018;13(8):e0201917. doi:10.1371/journal.pone.0201917

39. Ministry of Health Kenya. Sessional paper no 4 of 2012 on national pharmaceutical policy. reforming the pharmaceutical sector to ensure equitable access to essential health products and technologies for all Kenyans. Nairobi, Kenya; 2012. Available from: https://www.health.go.ke/wp-content /uploads/2020/11/Sessional-Paper-No.-4-of-2012National-Pharmaceutical-Policy-NPP.pdf. Accessed May $10,2021$.

40. Ashigbie PG, Rockers PC, Laing RO, et al. Availability and prices of medicines for non-communicable diseases at health facilities and retail drug outlets in Kenya: a cross-sectional survey in eight counties. BMJ open. 2020;10(5):e035132. doi:10.1136/bmjopen-2019-035132

41. Ministry of Health Kenya. Kenya harmonized health facility assessment 2018/2019 popular version. Nairobi, Kenya; 2019. Available from: https:// www.health.go.ke/wp-content/uploads/2020/01/KHFA-2018-19-Popular-version-report-Final-.pdf. Accessed August 10, 2021.

42. Selvaraj S. Ensuring access to medicines in East Africa: lessons from India. New Delhi, India: Observational Research Foundation; 2019. Available from: https://www.orfonline.org/wp-content/uploads/2019/07/ORF_OccasionalPaper_201_Pharma-India-Africa.pdf. Accessed September 02, 2021.

43. Ministry of Health Kenya. Kenya service availability and readiness assessment mapping (SARAM) report. Nairobi, Kenya; 2013. Available from: http://guidelines.health.go.ke:8000/media/Kenya_Saram_Report.pdf. Accessed September 02, 2021.

44. Dutta A, Maina T, Ginivan M, et al. Kenya health financing system assessment, 2018: time to pick the best path. Washington, DC: Palladium Health Policy Plus; 2018. Available from: http://www.healthpolicyplus.com/ns/pubs/11323-11587_KenyaHealthFinancingSystemAssessment.pdf. Accessed May 24, 2021.

45. Olaniran A, Briggs J, Pradhan A, et al. Stock-outs of essential medicines among community health workers (CHWs) in Low-and Middle-Income Countries (LMICs): a systematic literature review of the extent, reasons, and consequences. Preprint is under consideration at Human Resources for Health; 2021. Available from: https://assets.researchsquare.com/files/rs-692874/v1/2427d964-565f-45ee-a798-94ea3173b4b4.pdf?c=1631886254. Accessed October 28, 2021.

46. The World Health Organization. WHO definitions of substandard and falsified (SF) medical products. Geneva, Switzerland; 2017. Available from: https://www.who.int/medicines/regulation/ssffc/A70_23-en1.pdf?ua=1. Accessed May 24, 2021.

47. Ozawa S, Evans DR, Bessias S, et al. Prevalence and estimated economic burden of substandard and falsified medicines in low- and middle-income countries: a systematic review and meta-analysis. JAMA Netw Open. 2018;1(4):e181662. doi:10.1001/jamanetworkopen.2018.1662

48. Newton PN, Bond KC, Newton P. Oxford statement signatories. global access to quality-assured medical products: the Oxford statement and call to action. Lancet Glob Health. 2019;7(12):e1609-e1611. doi:10.1016/S2214-109X(19)30426-7

49. McManus D, Naughton BD. A systematic review of substandard, falsified, unlicensed and unregistered medicine sampling studies: a focus on context, prevalence, and quality. BMJ Global Health. 2020;5(8):e002393. doi:10.1136/bmjgh-2020-002393

50. Saraswati K, Sichanh C, Newton PN, et al. Quality of medical products for diabetes management: a systematic review. BMJ Global Health. 2019;4 (5):e001636. doi:10.1136/bmjgh-2019-001636

51. Nwokike J, Clark A, Nguyen PP. Medicines quality assurance to fight antimicrobial resistance. Bull World Health Organ. $2018 ; 96(2): 135$. doi:10.2471/BLT.17.199562

52. Ghanem N. Substandard and falsified medicines: global and local efforts to address a growing problem. Clin Pharm. 2019;11(5). doi:10.1211/ PJ.2019.20206309

53. Health Action International. Report prices \& availability of locally produced \& imported in Kenya. survey report. Amsterdam, The Netherlands; 2018. Available from: https://haiweb.org/wp-content/uploads/2018/07/Locally-Produced-and-Imported-Medicines-in-Kenya.pdf. Accessed May 24, 2021.

54. Ongarora D, Karumbi J, Minnaard W, et al. Medicine prices, availability, and affordability in private health facilities in low-income settlements in Nairobi County, Kenya. Basel Switzerland. Pharmacy. 2019;7(2):40. doi:10.3390/pharmacy7020040

55. Bruckner $\mathrm{T}$ The ignored pandemic: how corruption in healthcare service delivery threatens Universal Health Coverage. UK: Transparency International; 2019. Available from: http://ti-health.org/wp-content/uploads/2019/03/IgnoredPandemic-WEB-v2.pdf. Accessed October 28, 2021.

56. Gachane N Eight grilled over theft of Sh5m HIV kits from Murang'a hospital media report on theft by staff of HIV testing kits at Kenyan hospital. Nation.Africa; 2018. Available from: https:/nation.africa/counties/muranga/Sh5m-HIV-kits-stolen-Muranga-hospital/1183310-4663112-fmka4d /index.html. Accessed August 22, 2021.

57. Onwujekwe O, Odii A, Mbachu C, et al. Corruption in the Nigerian health sector has many faces. How to fix it. Braamfontein, South Africa: The Conversation Africa, Inc; 2018. Available from: https://theconversation.com/corruption-in-The-nigerian-health-sector-has-many-faces-how-to-fix-it -99043. Accessed August 22, 2021.

58. McPake B, Asiimwe D, Mwesigye F, et al. Informal economic activities of public health workers in Uganda: implications for quality and accessibility of care. Soc Sci Med. 1999;49(7):849-865. doi:10.1016/S0277-9536(99)00144-6

59. Agiresaasi A, Lindrio P, Segawa N. Fake and missing drugs “frustrate government's effort” to combat malaria in Uganda. Global Press Journal; 2019. Available from: https://globalpressjournal.com/africa/uganda/fake-missing-drugs-frustrate-governments-effort-combat-malaria-uganda/. Accessed August 22, 2021.

60. Mostert S, Sitaresmi MN, Njuguna F, et al. Effect of corruption on medical care in low income countries. Pediatr Blood Cancer. $2012 ; 58(3): 325$. doi: $10.1002 /$ pbc. 23408

61. Robinson JC. Funding of pharmaceutical innovation during and after the COVID-19 pandemic. JAMA. 2021;325(9):825-826. doi:10.1001/ jama.2020.25384 
62. Oberst N Unlocking access to healthcare in Kenya; avenues and stumbling blocks. Johannesburg, South Africa: The Brenthurst Foundation (Pty) Limited; 2021. Available from: https:/www.thebrenthurstfoundation.org/downloads/unlocking-access-to-healthcare-discussion-paper-002-3-.pdf. Accessed May 30, 2021.

63. Barasa E, Rogo K, Mwaura N, et al. Kenya national hospital insurance fund reforms: implications and lessons for universal health coverage. Health Systems Reform. 2018;4(4):346-361. doi:10.1080/23288604.2018.1513267

64. Munge K, Mulupi S, Barasa E, et al. A critical analysis of purchasing arrangements in Kenya: the case of micro health insurance. BMC Health Serv Res. 2019;19(1):45. doi:10.1186/s12913-018-3863-6

65. Azzani M, Roslani AC, Su TT. Determinants of household catastrophic health expenditure: a systematic review. MJMS. 2019;26(1):15. doi:10.21315/mjms2019.26.1.3

66. Salari P, di Giorgio L, Ilinca S, et al.. The catastrophic and impoverishing effects of out-of-pocket healthcare payments in Kenya, 2018. BMJ Global Health. 2019;4(6):e001809. doi:10.1136/bmjgh-2019-001809

67. Mollahaliloğlu S, Mouhoumed HM. Catastrophic health expenditures on accessing different healthcare services in Ethiopia and Kenya. Med Res Report. 2020;3(2):39-44.

68. Wirtz V, Hailu S, Rockers P, et al. Access to diabetes medicines at the household level in eight counties of Kenya. J Diabetol. 2018;9(2):45. doi:10.4103/jod.jod_32_17

69. Ministry of Health Kenya. Policy brief: a case for increasing public investments in health raising public commitments to Kenya's health sector; 2019. Available from: https://www.health.go.ke/wp-content/uploads/2019/01/Healthcare-financing-Policy-Brief.pdf. Accessed August 24, 2021.

70. Rockers PC, Laing RO, Ashigbie PG, et al. Effect of Novartis access on availability and price of non-communicable disease medicines in Kenya: a cluster-randomised controlled trial. Lancet Glob Health. 2019;7(4):e492-e502. doi:10.1016/S2214-109X(18)30563-1

71. Health Action International. Fact sheet. snakebite incidents, response \& antivenom supply (Kilifi County, Kenya). Kilifi. Kenya; 2019. Available from: https://haiweb.org/wp-content/uploads/2018/11/Fact-Sheet-Kilifi-County-Research-Snakebite.pdf. Accessed May 24, 2021.

72. McKague K, Menke M, Arasaratnam A. Access afya: micro-clinic health franchise designed for scale. In: Chapter 4: Social Franchising. Palgrave Macmillan; 2014:61-79.

73. Manji I, Pastakia SD. Novartis access: a small step towards increased access for non-communicable disease care. Lancet Glob Health. 2019;7(4): e398-e399. doi:10.1016/S2214-109X(19)30049-X

74. Kgaa M What is CURAFA ${ }^{\mathrm{TM}}$. Darmstadt, Germany; 2020. Available from: www.curafa.com. Accessed May $24,2021$.

75. Wirtz VJ, Hogerzeil HV, Gray AL, et al. Essential medicines for universal health coverage. Lancet. 2017;389(10067):403-476. PMID: 27832874; PMCID: PMC7159295. doi:10.1016/S0140-6736(16)31599-9

76. Moucheraud C, Lenz C, Latkovic M, et al. The costs of diabetes treatment in low- and middle-income countries: a systematic review. BMJ Glob Health. 2019;4(1):e001258. doi:10.1136/bmjgh-2018-001258

77. Government of Kenya. National Council for Law Reporting (Kenya Law). The pharmacy and poisons act number. CAP. 244 . Nairobi. Kenya; 2021. Available from: http://kenyalaw.org:8181/exist/kenyalex/actview.xql?actid=CAP.\%20244. Accessed August $24,2021$.

78. Wafula F, Abuya T, Amin A, et al. The policy-practice gap: describing discordances between regulation on paper and real-life practices among specialized drug shops in Kenya. BMC Health Serv Res. 2014;14(1):394. doi:10.1186/1472-6963-14-394

79. Wafula F, Molyneux C, Mackintosh Maureen, et al.. Protecting the public or setting the bar too high? Understanding the causes and consequences of regulatory actions of front-line regulators and specialized drug shop operators in Kenya. Soc Sci Med. 2013;97:220-227. doi:10.1016/j. socscimed.2013.08.020

80. Ministry of Health Kenya. Kenya National Pharmaceutical Policy; 1994. Available from: https://www.khidi.or.kr/fileDownload?titleId= 261268\&fileld=1\&fileDownType=C\&paramMenuld=MENU01872. Accessed February 17, 2022

81. Royal Media Services. World pharmacist's day; 2018. Available from: www.youtube.com/watch?v=98KSyfcdefM. Accessed May 20, 2021.

82. Wambulwa A. Pharmacy outfit wants unqualified technicians barred. The Star; 2019. Available from: https://www.the-star.co.ke/news/2019-04-04pharmacy-outfit-wants-unqualified-technicians-barred/. Accessed May 13, 2021.

83. Abuga K, Ongarora D, Karumbi J, et al. Sub-standard pharmaceutical services in private healthcare facilities serving low-income settlements in Nairobi County, Kenya. Basel. Switzerland. Pharmacy. 2019;7(4):167. doi:10.3390/pharmacy7040167

84. The OECD. Glossary of statistical terms: informal sector. International Labour Organization; 2003. Available from: https://stats.oecd.org/glossary/ detail.asp?ID=1350. Accessed July 13, 2020.

85. Pharmacy and Poisons Board. Guidelines for advertisements and promotion of medicines and medical devices in Kenya. Nairobi. Kenya; 2012. Available from: https://pharmacyboardkenya.org/files/?file=adv_guidelines.pdf. Accessed May 13, 2021.

86. Darrow JJ. Generic substitution by pharmacists could be cost saving in US. PharmacoEconomics Outcomes News. 2020;856(1):1. doi:10.1007/ s40274-020-6901-7

87. Darrow JJ, Chong JE, Kesselheim AS. Reconsidering the scope of US state laws allowing pharmacist substitution of generic drugs. BMJ. 2020. doi:10.1136/bmj.m2236

88. Orizio G, Merla A, Schulz PJ, et al. Quality of online pharmacies and websites selling prescription drugs: a systematic review. J Med Internet Res. 2011;13(3):e1795. doi:10.2196/jmir.1795

89. Miller R, Wafula F, Onoka CA, et al. When technology precedes regulation: the challenges and opportunities of e-pharmacy in low-income and middle-income countries. BMJ Global Health. 2021;6(5):e005405. doi:10.1136/bmjgh-2021-005405

90. Vida RG, Merczel S, Jáhn E, et al. Developing a framework regarding a complex risk based methodology in the evaluation of hazards associated with medicinal products sourced via the internet. SPJ. 2020;28(12):1733. doi:10.1016/j.jsps.2020.10.018

91. Baratto G. The illegal trade of medicines: the roles of the internet and social media websites. In: The Illegal Trade of Medicines on Social Media. Springer; 2020:7-35.

92. Bandivadekar SS. Online pharmacies: global threats and regulations. AAYAM AKGIM J Manag. 2020;10(1):36-42.

93. Gabay M. Regulation of internet pharmacies: a continuing challenge. Hosp Pharm. 2015;50(8):681. doi:10.1310/hpj5008-681 


\section{Publish your work in this journal}

Risk Management and Healthcare Policy is an international, peer-reviewed, open access journal focusing on all aspects of public health, policy, and preventative measures to promote good health and improve morbidity and mortality in the population. The journal welcomes submitted papers covering original research, basic science, clinical \& epidemiological studies, reviews and evaluations, guidelines, expert opinion and commentary, case reports and extended reports. The manuscript management system is completely online and includes a very quick and fair peer-review system, which is all easy to use. Visit http://www.dovepress.com/testimonials.php to read real quotes from published authors.

Submit your manuscript here: https://www.dovepress.com/risk-management-and-healthcare-policy-journal 